\title{
Kansalaisopiston tulisi palata yhteiskunnalliseksi vaikuttajaksi
}

\author{
Ensimmäisen työväenopisto käynnisti toimintansa sata \\ vuotta sitten. Kyseessä oli Tampereen työväenopisto, \\ nykyäänkin yksi maan suurimmista. Kaikkiaan Suomessa \\ toimii 274 kansalaisopistoa ja niiden piirissä opiskelee \\ vuosittain yli 600000 suomalaista. \\ Rehtori Leea Keto Evijärveltä kaipaa kansalaisopiston \\ paluuta yhteiskunnalliseksi vaikuttajaksi.
}

$\mathrm{L}$ eea Keto on toiminut pari vuotta Järviseudun kansalaisopiston rehtorina Etelä-Pohjanmaalla. Kansalaisopisto on neljän pikkukunnan yhteinen, Lappajärven, Evijärven, Vimpelin ja Kortesjärven. Hänen mielestään kansalaisopistojen tehtävät ovat aikojen saatossa ja yhteiskunnan muuttuessa muuttuneet:

- Kansalaisopistoliike syntyi ja levisi aikoinaan koulutuksellisen eriarvoisuuden tasoittajaksi, kouluttamaan kouluttamattomia. Peruskoulun tulon seurauksena tiedollisella opetuksella ei enää ollut samaa tilausta ja painopiste siirtyi ihmisten persoonallisuuden monipuoliseen kehittämiseen.

- Nykyisin kansalaisopiston olisi syytä ottaa takaisin vanhaa rooliaan yhteiskunnallisena vaikuttajana. Siihen on moniakin syitä, joista päällimmäisin on tietysti työttömyys ja syrjäytyminen. Kansalaisopistot voisivat ottaa varsin paljon vastuuta työelämästä tipahtaneiden pitämisessä aktiivisina. Toinen tärkeä syy yhteiskunnalliseen vaikuttamiseen on uhka alueiden koulutuksellisesta eriarvoistumisesta. Kun lukioita vähennetään, korkeampaa opetusta siirtyy kansalaisopistoille. Opistoilla on kaikkiaan suuri vastuu koko toiminta-alueensa kehittämisestä. Ainakin maaseutuopistoilla, jollainen meidän opistomme on, tehtävät lisääntyvät. Kaupunkiopistoilla tilanne saattaa olla erilainen. Kansalaisopistoliike voi ottaa yhteiskunnallista vastuuta siksi, että sen toiminta on hajautettu koko maan kattavaksi.

- Ei siis voida ajatella, että yksinomaan persoonallisuuden kehittäminen riittää nykypäivänä, vaan meidän tulee kertoa ihmisille, miten he voivat vaikuttaa omaan elinympärisöönsä.

Leea Kedon mielestä myös Euroopan Unionin jäsenyys on tuonut uusia, erilaisia tapoja vaikuttaa, eritoten Etelä-Pohjanmaalla, missä EU:n vastustus on ollut ainakin suuri:

- Ihmisten tulee tiedostaa yhteiskunnassa tapahtunut murros ja muutos ja oltava ajan tasalla. Kansalaisopistolla voi parhaimmillaan olla sellainen rooli, että siellä tiedetään, missä yleensä ottaen yhteiskunnassa mennään.

Järviseudun kansalaisopistossa painottuvat yleistä ihmisen hyvinvointia edistävät aineet, kuten kielet, kädentaidot ja liikunta. Uutena tärkeänä alueena toimintaan on tullut yhteistyö kylätoimintakoulutuksen kanssa. Hanke liittyy yhtenä osana maakunnalliseen kyläohjelmaan. Esimerkiksi Järviseudulle järjestetään hankkeen puitteissa hankeverstas, jossa mietitään, miten ideasta tulee totta ja miten idean muuttaminen toiminnaksi rahoitetaan. 
- Olemme myös keränneet ideoita kyläläisiltä. Sitä kautta ovat nousseet tärkeiksi koetuiksi taidoiksi ihmissuhde- ja vuorovaikutustaidot, itsetunnon ylläpito, yksilön ja yhteisön voimavarojen käyttö sekä EU:n mahdollisuudet. Kylätoimintahankkeesta kylätason koulutus kanavoituu kansalaisopistojen kautta, kertoo rehtori Leea Keto.

\section{Mitäkansalaissyhmiäkansalaisopistohahuaisitowoittaaparemmin kuinnyt? Mitäkeinojasiihenvoisiolla?}

- Kaikkihan tiedämme, etteivät miehet osallistu yhtä aktiivisesti kansalaisopiston toimintaan kuin naiset. Syynä voi olla se, ettei kansalaisopisto onnistu tarjoamaan miehille heitä kiinnostavia aiheita, tai se, että miehiä ei tämäntyyppinen opiskelumuoto houkuttele. En pidä tätä kuitenkaan suurena ongelmana.

- Kentältä pitäisi saada enemmän tietoa siitä, mitä ihmiset toivovat ja pitävät tärkeänä. Ihmiset eivät tule ajatelleeksi, että he voisivat vaikuttaa hyvinkin konkreettisesti opetusohjelmien sisältöihin. Opetusohjelmathan muuttuvat ja joustavat, ja niissä voidaan kuulla ihmisten tarpeita.

Leea Keto muistuttaa siitä, että pian kansalaisopistojen asiakkaina on iso ryhmä virkeitä eläkeläisiä, joka on syytä suunnittelussa muistaa.

Kun määrärahat ovat kovin rajalliset, painopisteitä on tarkkaan harkittava. Opistoilla on paineita lisätä iltapäiväkerhoja. Leea Keton mielestä on kuitenkin mietittävä, mikä lopultakin on opiston tehtävä, onko se oppimisessa vai kerhotoiminnassa:

- Minusta painopisteen tulee olla aikuisten oppimisessa. Vieläkin keskeisempää olisi kuitenkin saada järkevää toimintaa nuorille, nimenomaan syrjäytymisuhan alla oleville nuorille. Se on kansalaisopistoille suuri tehtävä.

\section{Mitkäovatkansalaisopistolïkkeensunrimpiaongelmiajauhkakut vid?}

- Ainakin maaseutuopistoissa uhkana on maaseudun väen väheneminen, nimenomaan aktiivin väen väheneminen. Kysymys yksinkertaisesti kuuluu: pysyykö maaseutu asuttuna?
Kansalaisopistot ovat valtion ja kuntien ylläpitämiä ja siksi niissä toimii kontrolli. Niiden kurssimaksut eivät edelleenkään ole päätähuimaavia. Mutta jos yksityisille koulutusfirmoille annetaan koulutusvastuuta, kuten näyttää, tilanne muuttuu. Koulutusfirmat antavat koulutusta rahan edestä ja rahan vuoksi. Kansalaisopistojen tavoitteena ei ole taloudellisen voiton tavoittelu, mutta koulutusfirmoilla on. Tämä koskee ennen kaikkea EU-projekteihin liittyvää koulutusta.

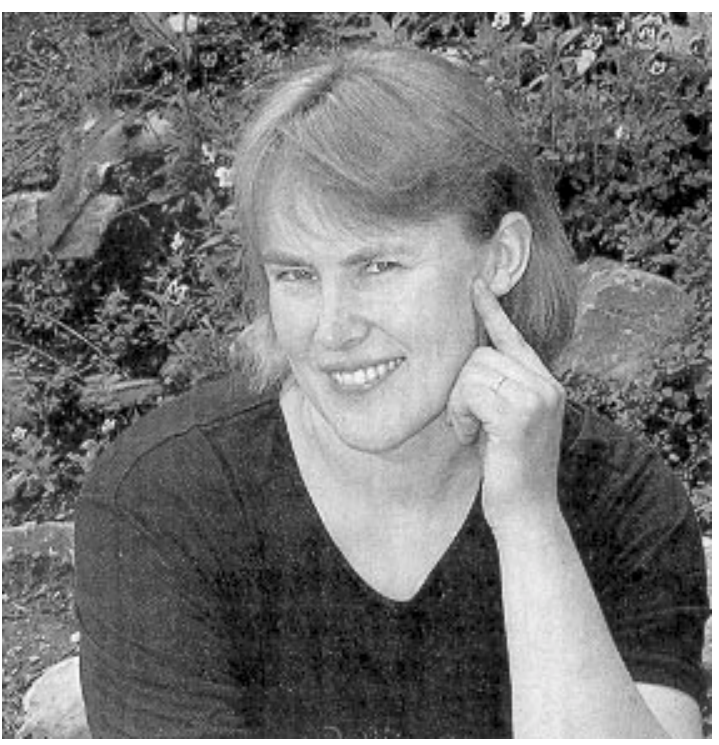

\section{Millätovallahahuattekehittääopistoannetaiopistoliikettä? Mitäse voisiparhaimmillaanolla?}

- Puhun mieluiten maaseutukansalaisopiston kehittämisestä, sillä uskon sen myös jatkossa poikkeavan toiminnaltaan kaupungissa toimivasta opistosta. Näen tulevaisuudenvisiona sen, että pienillä paikkakunnilla kansalaisopisto voisi ottaa itselleen koordinaattorin tehtävän. Nythän jo monet eri tahot tekevät mielellään yhteistyötä kansalaisopiston kanssa - kulttuuri, vapaa-aika, nuorisotyö, liikunta, koulutus. Kansalaisopisto voisi olla monialainen kehittämiskeskus. Nyt koulutusta suunnitellessa joudutaan selvittämään, onko jokin muu taho järjestämässä vastaavanlaista koulutusta, ettei tehdä turhaan päällekkäistä työtä. Opistot voisivat koordinoida omalla toiminta-alueellaan annettavaa koulutusta.

Anneli Kajanto 